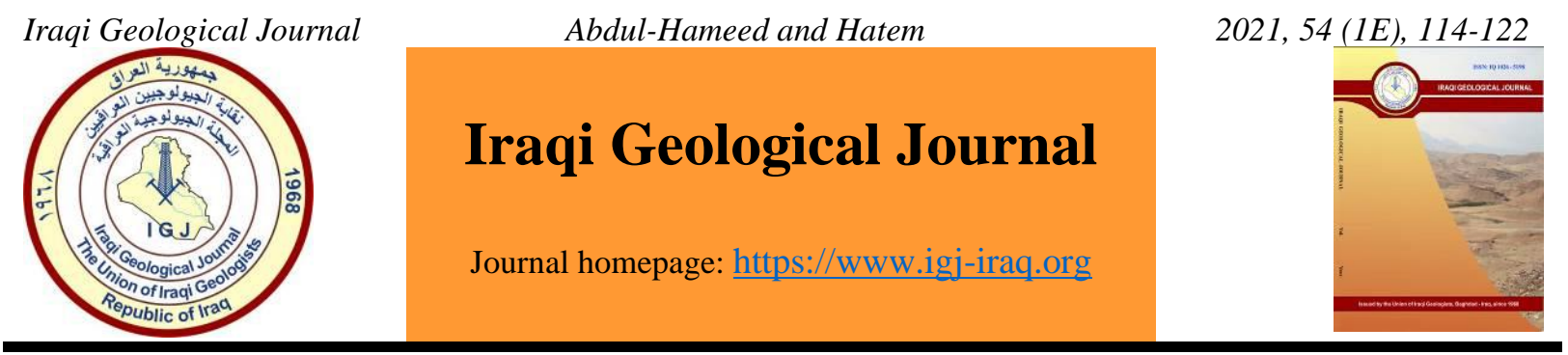

\title{
Effect of Shatt Al-Arab Salinity on the Groundwater of Al-Fao and Al-Siba in Southern Iraq
}

\author{
Shahad Abdul-Qadir Abdul-Hameed ${ }^{1,}$, Amal Jabbar Hatem² \\ ${ }^{1}$ Department of Physics, College of Education for Pure Science (Ibn-Al-Haitham), University of Baghdad \\ ${ }^{2}$ Department of Physics, College of Education for Pure Science (Ibn-Al-Haitham), University of Baghdad \\ *Correspondence: Shahed.Abd1204a@ihcoedu.uobaghdad.edu.iq
}

Received: 2 December 2020; Accepted: 19 March 2021; Published: 31 May 2021

\begin{abstract}
This study was conducted to estimate the extent of damage to the population in Basra, southern Iraq, specifically the areas adjacent to the Shatt al-Arab and the Arabian Gulf, which are the Al-Fao district and the Al-Siba region. They are affected by the progression of saline water resulting from the lack of water imports and the Karun River interruption, which led to high concentrations of salts in the Shatt Al-Arabs. Consequently, its effect on lands and all life types in these areas requires correcting a map of the study area to drop the groundwater sites as well as calculate the total dissolved salts, electrical conductivity and $\mathrm{pH}$. This study concluded that the groundwater contains very high percentages of total dissolved solids $(2880-10415 \mathrm{mg} / \mathrm{l})$ and electrical conductivity $(4450-14190 \mu \mathrm{s} / \mathrm{cm})$. As it has very high salinity, so it is not suitable for drinking, irrigation, or industry. The values of the $\mathrm{pH}$ values (7.1-7.5) indicate that it is a light alkaline.
\end{abstract}

Keywords: Groundwater; Shatt al-Arab; Electrical Conductivity; Total Dissolved Solids

\section{Introduction}

Groundwater is the third resource after surface water and rainwater, and it is one of the main sources of river water in the world, as the source of this water is water that infiltrated from the surface of soils with high porosity towards the formation of the earth's crust and then later becomes reservoirs or so-called underground reservoirs. The importance of groundwater in increasing its use day after day after another, due to the increase in the need for it in the provision of drinking and irrigation water in many countries of the world, and as a result, it has become very important to study the quality and quantity of this water to ensure the continuity of its availability (Al-Khafaji, 2015) (Abo al-Somur, and Al-khateeb, 1999).

The quality of this water can be compared with internationally approved standards or Locally to find out their suitability for human use, and this can be achieved by taking random samples from them and analyzing them in a laboratory to find out their physical and chemical properties, such as knowing their salinity, electrical conductivity (EC)values, their interaction rate, and others, As the concentrations of dissolved solids reflect some of the physical and chemical characteristics of water such as salinity, water quality and areas of use (Al-Dabbas and Kadhim, 2017), as for EC, this variable reflects the ability of water to conduct electric current and its relationship directly to the amount of dissolved solids. As for DOI: 10.46717/igj.54.1E.10Ms-2021-05-31 
the $\mathrm{pH}$ of the population, it expresses the concentration of hydrogen ion in the water, as its increase from 7 expresses its direction towards the basicity, while its decrease from 7 is an indicator of acidity, where the number 7 indicates the degree of neutralization, which is known as the ideal degree for freshwater suitable for drinking and use Human. (Abawi and Muhammed, 1990) (Boyahna, 1979) (Al-Heity, 2003). Knowledge of groundwater salinity evaluates its suitability for use. It was found through the field visit and fieldwork that the depths of groundwater wells in the study area vary, but most of the groundwater in this area is close to the surface, as its depth ranges between 0.50-1.50 meters. these formations contain salts, which increases their salinity (Ali et al., 2021).

As a result of increased evaporation and the rise of the groundwater level to the critical depth, where the critical depth depends on the concentration and quality of salts in the groundwater, the higher the concentration of salts leads to an increase or rise in groundwater (Fatah et al., 2020). Some studies have shown that the presence of some salts such as chlorides increases the movement of water with the capillary property as the critical depth is also affected by the soil texture, and the critical depth of water decreases with the increase in soil softness, in addition, to influence the rate of evaporation and the amount of precipitation falling on groundwater movement by capillary property (AL-Aniy, 1984)(Al-khayat, 2012) Where remote sensing technology was used in this study to correct the satellite image for 10/28/2020 and deduct the study area and deduct the study area. Therefore, the use of modern technologies represented in geographic information systems (GIS), specifically (QGIS), is of great importance in this study, as this study was carried out by taking samples randomly distributed over the study area and analyzing them in a laboratory to find out their suitability for human uses, where the total salts were calculated. Solubility, EC, $\mathrm{pH}$, and the distribution of the obtained values on the map of the study area.

The research problem is summarized in the study of the extension effect of the salty tongue of Shatt al-Arab on the groundwaters, a field study in the area which is located within the Basra Governorate in the year 2020. Shatt al-Arab phenomenon of the tide inside the province. As well as finding the appropriate method in spatial analysis to distribute the values of the concentrations of the qualitative characteristics of groundwater and its suitability for use.

\section{Study area}

The study area is located in southeastern Basra (Fig.1a). It covers an area of about $768 \mathrm{~km}^{2}$ of the total area of Iraq (Fig.1b). Its coordinates are $31^{\circ} 20^{\prime} 40.72^{\prime \prime} \mathrm{E}-29^{\circ} 15^{\prime} 9.28^{\prime \prime} \mathrm{N}$ and $47^{\circ} 41^{\prime} 47.311^{\prime \prime} \mathrm{E}-50^{\circ}$ $9^{\prime} 20.91$ "N. The study area is bordered from the north side by the Shatt al-Arab, from the south by the Arabian Gulf, from the east to Iran and Gharbanah Um Qasr.

\section{Materials and Methods}

Many steps have been done and can be described as follows:

The geometrical distortion of the satellite images occurs for several reasons, including random or non-random, as it is necessary to correct this distortion before starting to use the image. Correction accuracy depends on the ground control points (GCPS) (Chong and Chris, 1998). Correction is done either in a picture-to-picture or picture-to-map method. Using the ENVI software to create a mosaic between two images, and the image-to-image correction method, then use the QGIS software to correct an image to a map by linking the locations of the ground points (GCPS) together for both the satellite image taken for the study area and the administrative map of the same area, also called the reference image. The correction mechanism is carried out by linking the location of the image to the positions on the map. It is preferable to have more than seven ground points to calculate the polynomial model, and this model is known as the simplest model that can deal with the requirements of non-attribution and is used to correct scanned maps or satellite visuals. 


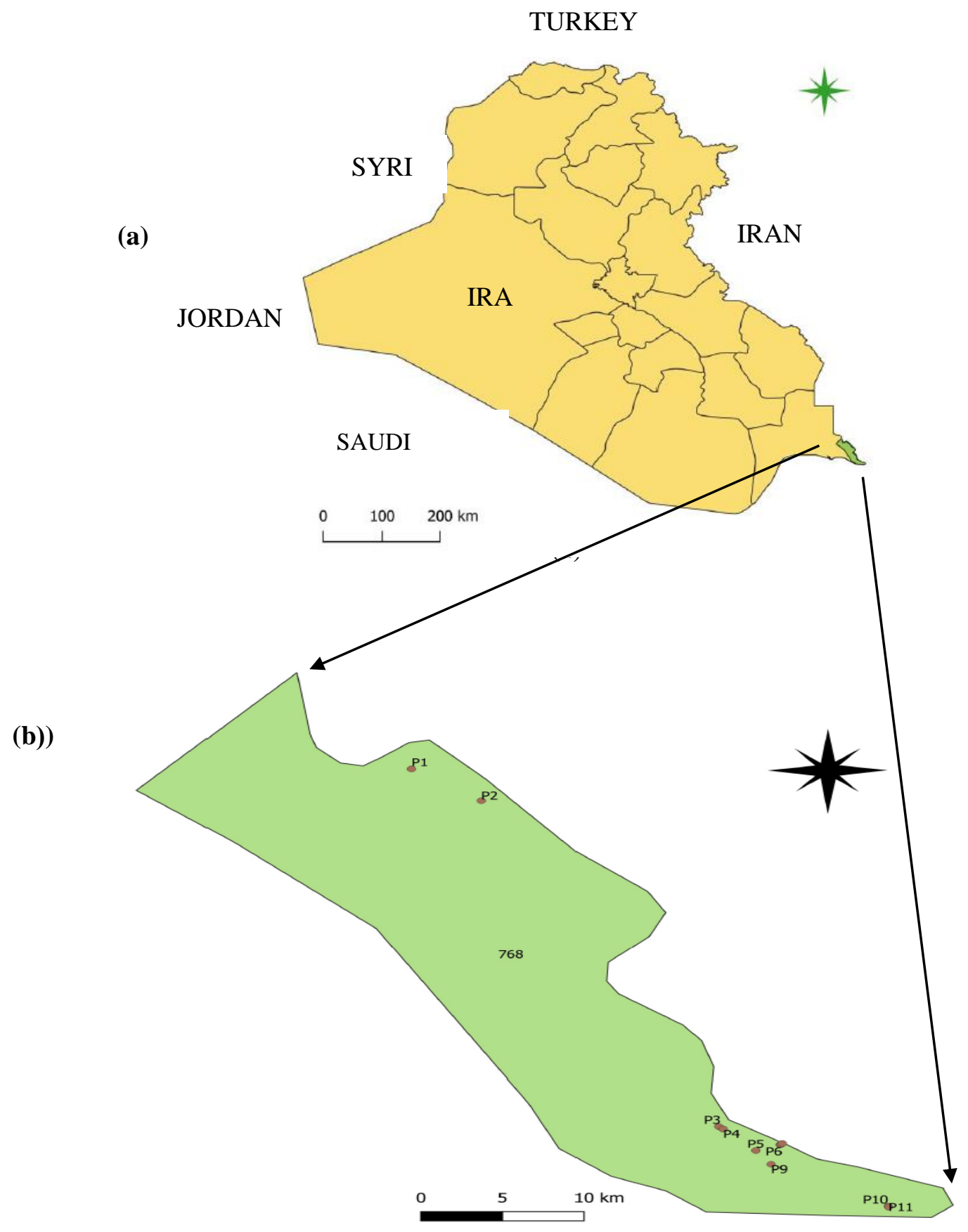

Fig. 1. The location of the study area (a); and its surface area in $\mathrm{km}^{2}$ (b)

The Landsat 8 satellite image was used for the date 28 Oct 2020. The satellite visual was converted from digital to reflective using ENVI software based on the following reflectivity equation (1) (Mahdi and Abduljabbar, 2019):

$\mathrm{T} \lambda^{\prime}=((\mathrm{Yp} * \mathrm{Vcal})+\mathrm{Zp}) / \sin \theta$

$T \lambda^{\prime}$ : TOA Planetary Spectral Reflectance.

$Y p$ : Reflectance multiplicative scaling factor for the band.

$Z p$ : Reflectance additive scaling factor for the band. 
$\sin \theta$ : Solar elevation angle.

Vcal: Pixel value in DN.

After converting the image to the reflection format, all image beams except the thermal and panchromatic were combined in one layer. The study area was deducted from the satellite image of the Landsat 8 satellite using the program (QGIS). Eleven groundwater samples were randomly collected using the Ukr. The samples were analyzed in the laboratories of the Ministry of Water Resources, the General Authority for Ground Water to find the values of Total Dissolved Solids (TDS), (EC) and pH (Table 2). The results of the samples were obtained from the previous step and projected onto the cut-out map of the study area using the program QGIS that was used to display the spatial analysis of the values obtained from the laboratory analysis and their spatial distribution on the map of the study area. The relationship between the TDS that obtained from analyzing the samples in the previous step with the positions, as well as the values of EC with the positions and find the relationship between these two factors with $\mathrm{pH}$ values.

Table 1. Registration parameters according to the GCPS method

\begin{tabular}{ccccc}
\hline GCP No. & \multicolumn{2}{c}{ Warp ALI map } & \multicolumn{2}{c}{ Base TM scene, 2020 } \\
\hline & $\mathrm{X}$ & $\mathrm{Y}$ & $\mathrm{X}$ & $\mathrm{Y}$ \\
\hline 1 & 30.51000000 & 48.02777778 & 7502.000000 & 5432.000000 \\
2 & 30.99777778 & 48.03000000 & 7432.000000 & 3502.000000 \\
3 & 31.00083333 & 47.68361111 & 6370.000000 & 3526.000000 \\
4 & 29.87638889 & 48.67861111 & 9377.000000 & 7430.000000 \\
5 & 30.05555556 & 48.19638889 & 8058.000000 & 7020.000000 \\
6 & 30.46472222 & 47.45055556 & 4702.000000 & 5196.000000 \\
7 & 30.91138889 & 46.47555556 & 2422.000000 & 3884.000000 \\
8 & 29.10638889 & 46.54777778 & 2770.000000 & 10655.000000 \\
9 & 30.96944444 & 46.03888889 & 1022.000000 & 3689.000000 \\
10 & 29.59722222 & 48.14194444 & 7930.500000 & 8740.750000 \\
11 & 30.10361111 & 47.37111111 & 5326.000000 & 6935.000000 \\
\hline
\end{tabular}

\section{Results and Discussion}

\subsection{TDS}

The water salinity of groundwater ranges between $2880-10415 \mathrm{mg} / \mathrm{L}$. Fig. 2 shows the distribution of the obtained values of the TDS in the study area, which is not in conformity with the Iraqi specifications and the specifications of the World Health Organization (WHO) for drinking (500-1500) $\mathrm{mg} / \mathrm{L}$.

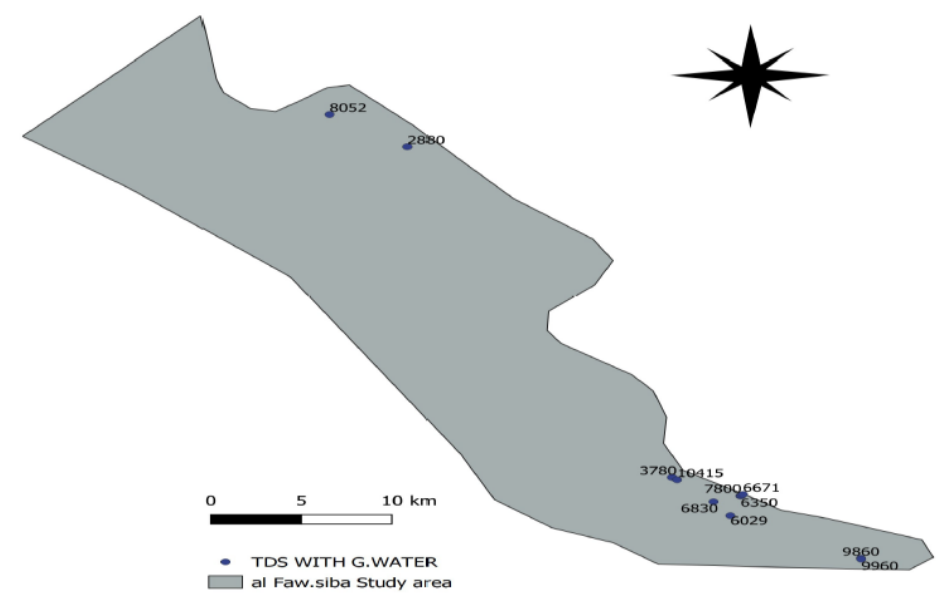

Fig. 2. The total dissolved salts distribution in the study area 
As for their distribution, they are divided into two categories:

The first Category: It is represented the type of saline water and constituted a percentage $18 \%$ of the total number of studied wells, where the percentage of dissolved salts ranged 2880-3780 mg $/ \mathrm{L}$.

The second category: The type of highly saline water represented a percentage $82 \%$ of the total number of studied wells, where the percentage of dissolved salts ranged between (6029-10415) $\mathrm{mg} / \mathrm{L}$ (Table 2).

Table 2. The fieldwork results after laboratory analysis and comparison with the Iraqi determinants and the WHO determinants

\begin{tabular}{ccccc}
\hline position & Parameters & EC $(\boldsymbol{\mu s} / \mathbf{c m})$ & pH & TDS (mg. L-1) \\
\hline & WHO Limits & $500-750$ & $7-8.5$ & $500-1000$ \\
P1 & Iraqi Standards & $750-1500$ & $6.5-8.5$ & $500-1500$ \\
P2 & Siba & 12560 & 7.15 & 8052 \\
P3 & Siba-fao way & 5880 & 7.2 & 2880 \\
P4 & Siba-abadan border & 4450 & 7.23 & 3780 \\
P5 & Project al fao port & 9090 & 7.2 & 10415 \\
P6 & Fao-inside city & 8620 & 7.1 & 6830 \\
P7 & Fao-outside city & 8730 & 7.1 & 6350 \\
P8 & Alfao-the sea & 9580 & 7.1 & 7800 \\
P9 & Fao-port of fishing & 13930 & 7.2 & 6671 \\
P10 & Shatt Al Arab-fao & 10310 & 7.2 & 6029 \\
P11 & Rass al-bisha & 13300 & 7.1 & 9860 \\
\hline
\end{tabular}

Based on the results obtained from this study, it can be concluded that the groundwater in the study area contains high salt concentrations. The soil in this area is characterized by high porosity, as well as the proximity of groundwater to the surface where this water reaches a critical depth $(0.5-1.5) \mathrm{m}$, as well as the nature of the study area and the proximity of the Shatt al-Arab to the sites from which the samples were taken has a great impact on the results obtained, as it is known that the high level of salinity of its water has led to great problems for this area due to the phenomena of tides and the entry of salty water into the area. It led to a deterioration in the water and agricultural conditions.

It was noticed through the field obtained results that the salinity was lower at position 2 which is in the Siba-fao way region, because the site is far from the Shatt al-Arab, and the salinity was higher at position 4 in the area adjacent to the project al-fao port. Fig.3 illustrates the distribution of Total Dissolved Salts (TDS) as a function of the position.

\subsection{PH}

The $\mathrm{pH}$ values give a slight alkaline to the wells under study and still within the permissible limit for both the Iraqi specifications and the WHO specifications (6.6-8.5) $\mathrm{mg} / \mathrm{L}$ (WHO, 1984) (Abawi and Muhammed, 1990). It was noticed that the lowest $\mathrm{pH}$ value was at sites $1,5,6,7,10$, that is, in the areas adjacent to the Shatt al-Arab and the Arabian Gulf (Fig. 5). Its highest value was at position 11 in the Rass -Albisha region. The $\mathrm{pH}$ value decreases as we move away from the surface water sources represented by the Shatt al-Arab and the Arabian Gulf, and it increases as we move away from these sources. Fig. 5 illustrates the distribution of $\mathrm{pH}$ values as a function of location. 


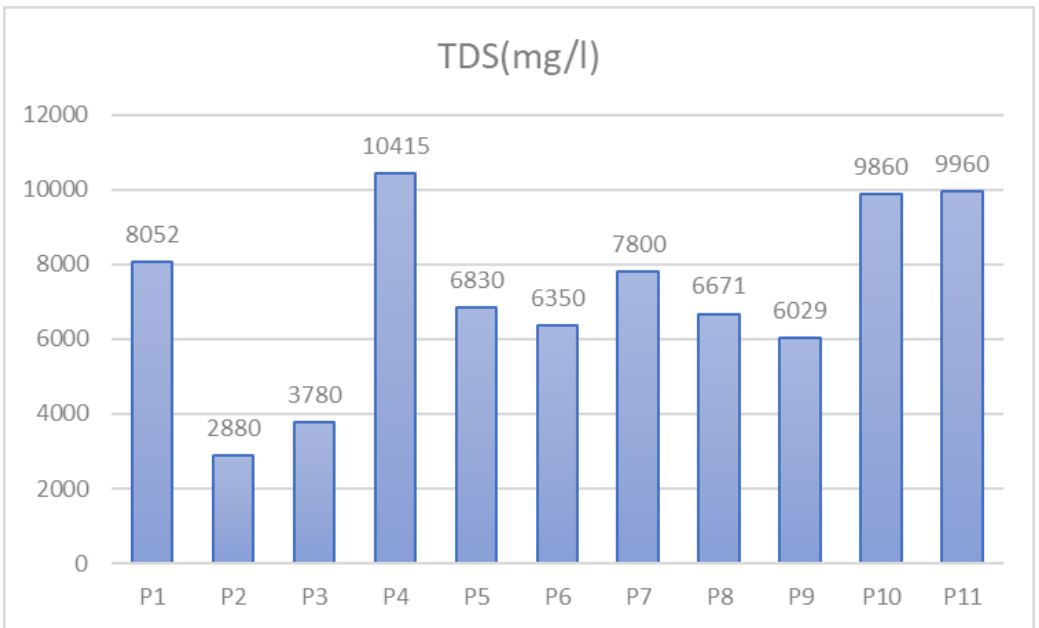

Fig. 3. the total dissolved salts distribution as a function of the position

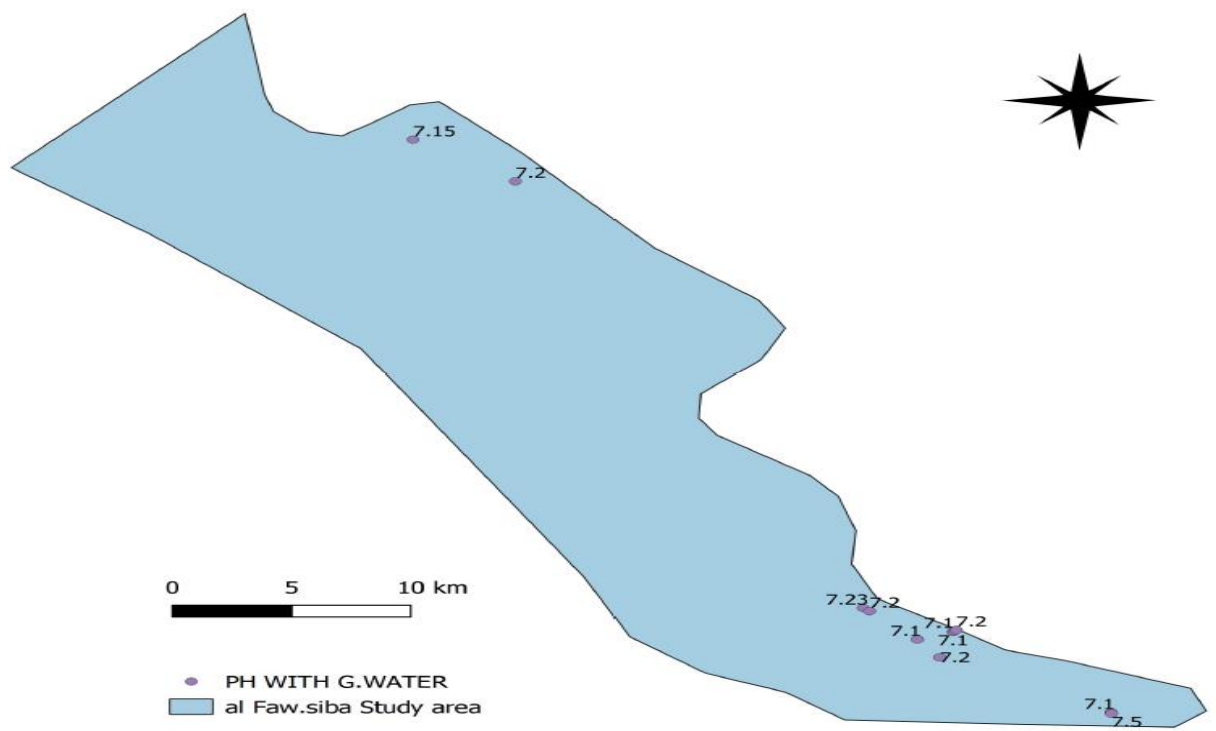

Fig. 4. The $\mathrm{pH}$ values distribution over the study area

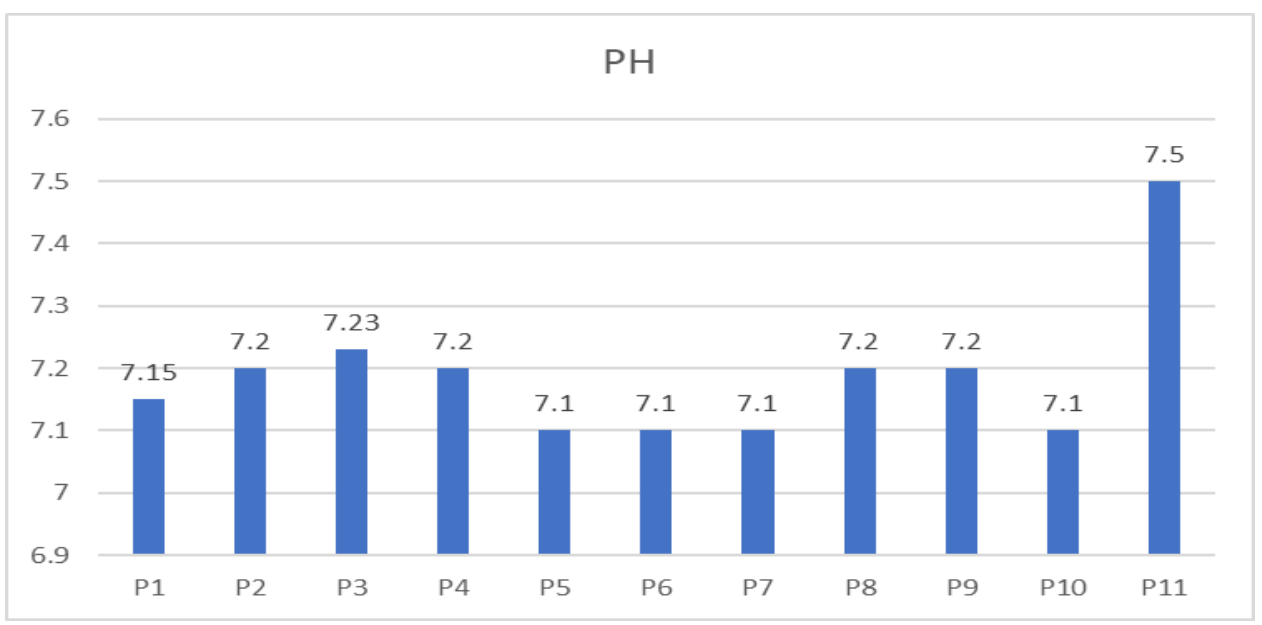

Fig. 5. The distribution of $\mathrm{pH}$ values as a location function 


\subsection{Electrical Conductivity}

Table 2 shows that the conductivity values ranged between 4450-14190 $\mu \mathrm{s} / \mathrm{cm}$. When compared with the Iraqi and international standards permissible for drinking water of 750-1500 $\mu \mathrm{s} / \mathrm{cm}$, Fig.6 shows the distribution of values over the area it is extremely high, as this rise is due to the high concentrations of dissolved salts. The EC of the wells in the study area was divided into two categories:

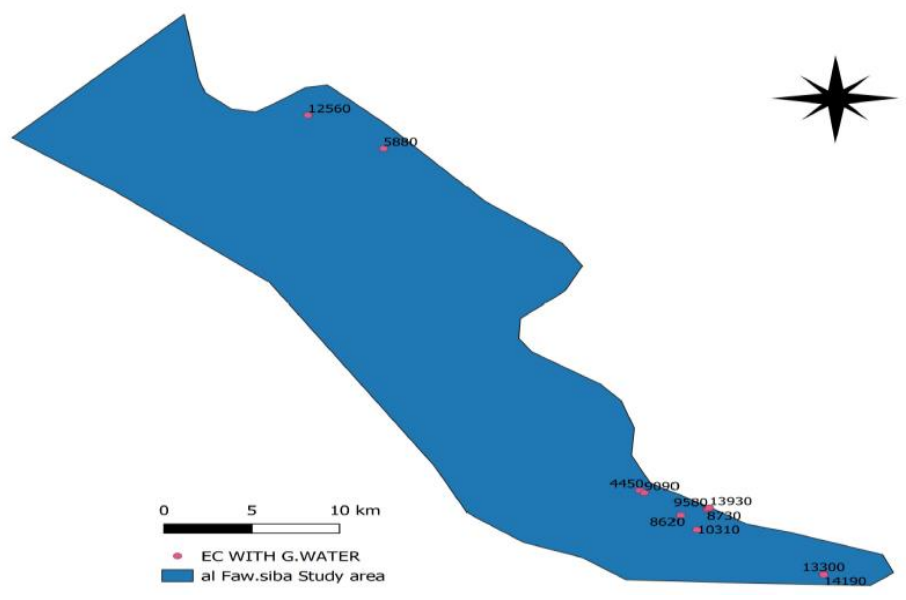

Fig. 6. The EC values distributed on the study area

First category is characterized by a type of saline water that is represented $36.4 \%$ of the total studied wells, where the EC ranged between $4450-8730 \mu \mathrm{s} / \mathrm{cm}$. The second category is represented the highly saline water of $63.6 \%$ of the total studied wells, where the conductivity values of this category ranged between $4450-14190 \mu \mathrm{s} / \mathrm{cm}$. It was observed through the fieldwork that the lowest value of the conductivity was at position 3, As shown in Fig. 7, which is in the border area Seiba-Abadan and not adjacent to the Shatt al-Arab, and the greatest value obtained for EC was at positions 8,11 where position 8 represents the fishing port area on the coast $\mathrm{Al} \mathrm{Arab,} \mathrm{and} \mathrm{position} 11$ represents the Ras $\mathrm{Al}$ Bisha area from the Arabian Gulf near. Fig. 8 illustrates the distribution of the obtained EC values as a function of location, It was found through the obtained results that the high EC is directly proportional to the height of the total dissolved salts, as in the Fig. 8.

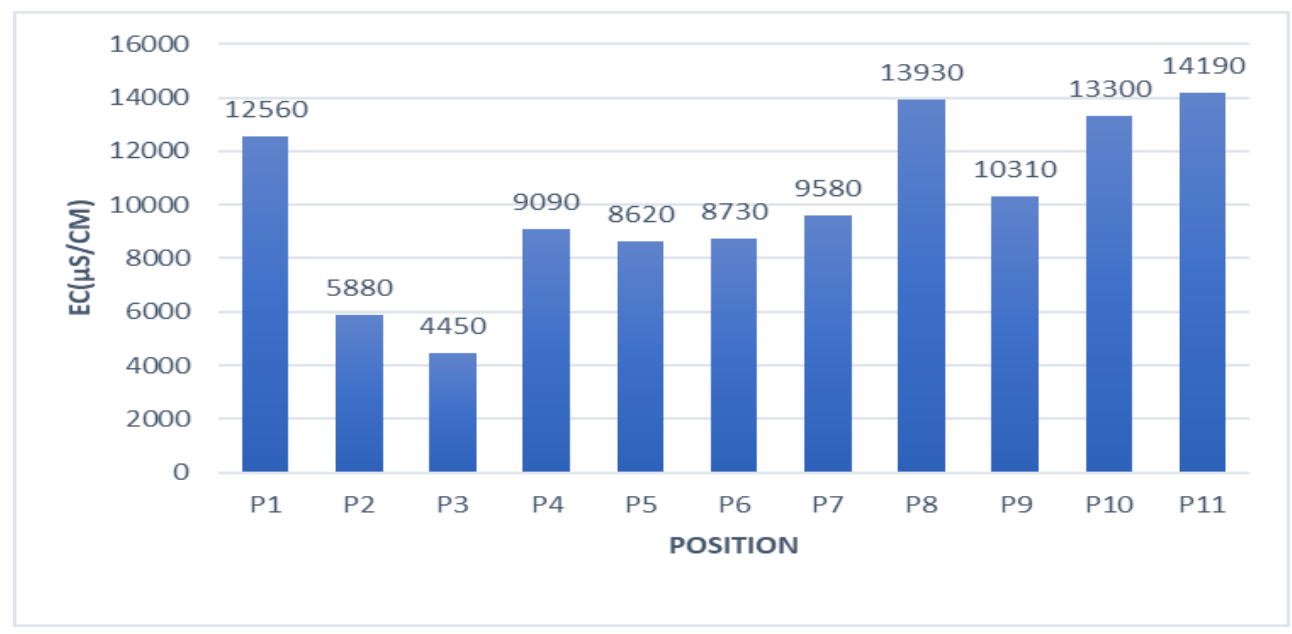

Fig. 7. The distribution of the obtained EC values as location function 


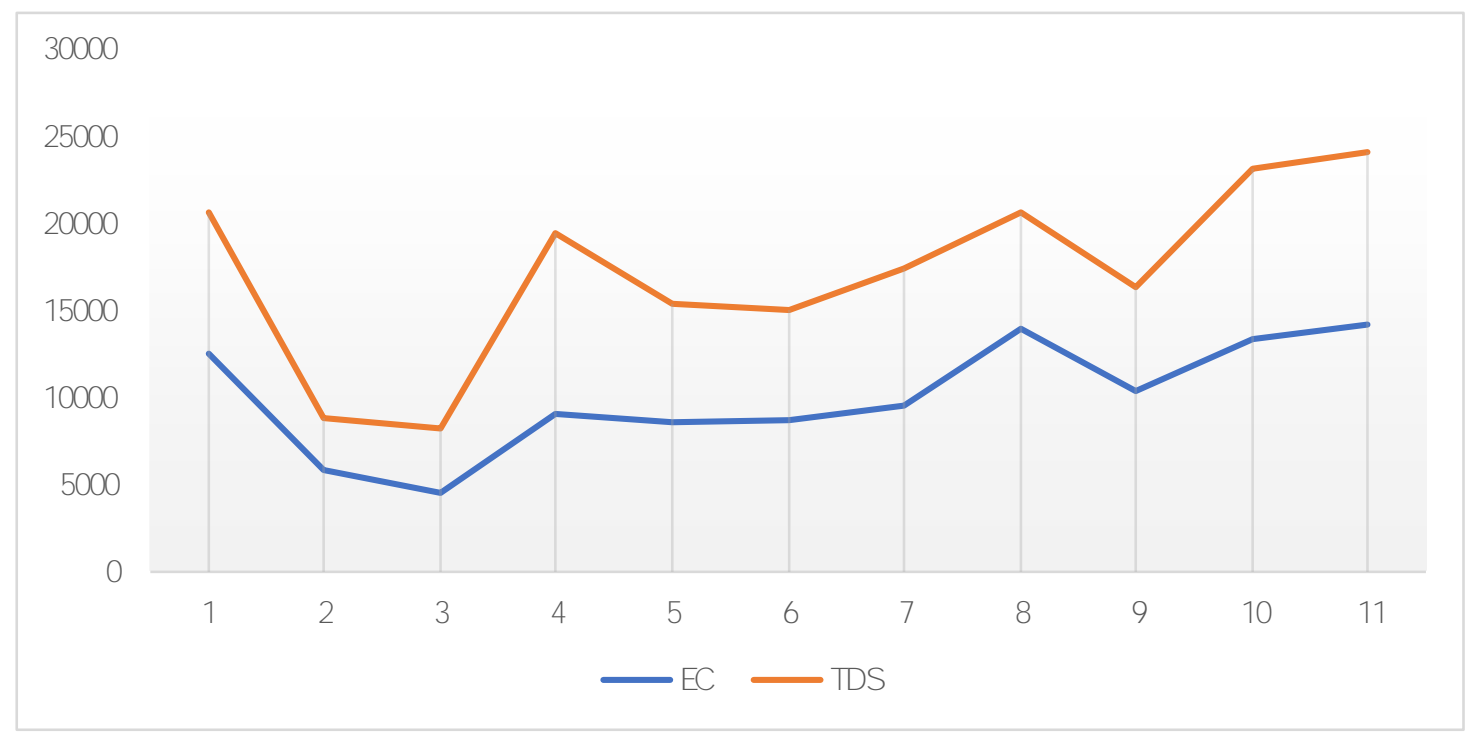

Fig. 8. Distribution of the EC and the TDS in the sampling site in the study area

\section{Conclusions}

This study concluded that the groundwater in the study area contains extremely high percentages of TDS ranging between 2880 and $10415 \mathrm{mg} / \mathrm{l}$ with an EC varying from 4450 to $14190 \mu \mathrm{s} / \mathrm{cm}$. As these characterizations, the groundwater is not suitable for drinking, irrigation and industry based on the Iraqi and the WHO specification. The importance of this study is summarized in assessing the extent of damage caused by the advancement of salty water towards the cities of Basra Governorate, specifically the cities located in the far south of the governorate, as these areas suffered from the scarcity of drinking water and the near absence of agriculture.

\section{Acknowledgements}

The authors are incredibly grateful to the Editor in Chief Prof. Dr. Salih M. Awadh, the Secretary of Journal Mr. Samir R. Hijab. and the Technical Editors for their great efforts and valuable comments.

\section{References}

Abawi, S. B., Muhammed, S. 1999. Practical environmental engineering (water assays), Dar al-Hekma, 50-89, 255-258.

Abo al-Somur, H., Al-khateeb, H., 1999. Geography of water resources. Safaa Publishing House, 155 pp.

Al-Aniy, A. 1984. Basics of soil science, Art Institutes Press.

Al-Dabbas, M. A., Kadhim, S. O., 2017. Evaluate the groundwater suitability for irrigation in Dujaila area-Wasit Governorate -Middle of Iraq, Iraqi Geological Journal, 50.

Al-Heity, S. 2003. Statistical methods in administrative sciences (applications using spss). Amaan: Dar-Wael.

Al-Khafagy, S. 2015. Water resources in the southern desert of Iraq and their investment. college of Literature, 111 pp.

Al-khayat, N. 2012. Ground water in Al-Faw district and its environmental impacts. Basra Studies Journal.

Al-Shamaa, A. 1993, Hydrological and tectonic study of the western part of the Western Sahara. Baghdad University.

Ali, A. H., Al-Shamaa, A. M., Ali, K. K., 2021. Hydrochemistry of the Dammam Unconfined Aquifer Southern Desert, West Iraq. Iraqi Geological Journal, 54, 84-98.

Boyahna, A., 1979. Increase of dissolved salts in surface water in Iraq and its relationship to reclamation. Baghdad: Public Corporation for Soil and Land Reclamation Ronyo. 
Chong, A. K, Chris, P.,1998. Geometrically corrected digital images for resource mapping and precision farming, Proceedings of the Spatial Information Research Centre's, 64-69.

Fatah, K., Hamed, M., Saeed, M. H., and Dara, R., .2020. Evaluation groundwater quality by using GIS and water quality index techniques for wells in Bardarash area, Northern Iraq. Iraqi Geological Journal, 53, 87-104.

Mahdi, M. H. and Abduljabbar, H. M. ,2019. An analytical study of soil temperature with respect to its salinity, in AIP Conference Proceedings, p. 020009.

WHO,1984. Guide Lines for drinking Water Quality, Geneva, 83-92. 